\title{
INVESTIGATING THE EFFECT OF SOCIOSCIENTIFIC ISSUES-BASED INSTRUCTION ON THE ACADEMIC ACHIEVEMENT OF STUDENTS: A MIXED-RESEARCH SYNTHESIS
}

\author{
Cüneyt Akyol ${ }^{1}$ \\ Aksemseddin Science and Art Center, Turkey
}

Sedat Kanadli

Mersin University, Turkey

\begin{abstract}
This synthesis aims to see the effects of Socio-scientific Issues- Based Instruction (SSI) on the academic achievement of students in Turkey and to help shape future studies on this topic. A mixed-research synthesis method was employed in this study. As a result of the data searching process, 12 studies with quantitative data and 6 studies with qualitative were included in the synthesis. The quantitative studies were analysed through a meta-analysis and the qualitative studies were analysed through thematic synthesis method. As a result of the meta-analysis it was determined the SSI had strong and significant on $(g=1.076,95 \% \mathrm{CI}[0.724,1.428])$ on academic achievement. In addition, it was determined that the calculated common effect size differed significantly according to the school level and the education program applied. As a result of the thematic synthesis six analytic themes were formed. It was attempted to explain the variance between studies included in the meta-analysis, using the analytical themes obtained from the thematic synthesis. As a result of the analysis, it was determined that SSI should be done outside the classroom, experts should be invited to these activities, teachers should be trained on this subject and a special education program should be prepared.
\end{abstract}

Keywords: Socio-scientific issues, academic achievement, meta-analysis, thematic synthesis, mixed-research synthesis.

\section{Introduction}

The purpose of the science curriculum is to enable individuals to become science literate (MEB, 2018, p.9). Science literates are expected to be individuals who investigate, question, make effective decisions, identify the problems around them, and create

${ }_{1}^{1}$ Correspondence: cakyol51@gmail.com 
solutions to these problems. It is an undeniable fact that changes occur in the social structure of societies along with the developing technology. Sometimes, these changes bring along some problems. Therefore, it is of great significance to raise individuals who look at these social problems from a scientific perspective. In this context, socioscientific issues (SSI) featured in the science curriculum deal with the innovations that enter our lives with the changing and developing technologies, and the contents are arranged for students to investigate on these issues using their scientific process skills and to produce solutions to the emerging problems. Some of these problems can be located in socioscientific issues.

\section{Theoretical Framework}

Socio-scientific issues are scientific issues that are closely related to society. For this reason 'socioscientific issues' are descripet as controversial issues arising from the integration of science and society (Sadler 2004, p.531). Socioscientific issues are societal issues that science deals with, such as climate change, vaccines, genetically modified organisms, and the current Covid-19 pandemic (Herman et al., 2022, p. 1). Topçu (2010), however, defined SSI as complex, open-ended, and commonly discussed issues with no specific solution to achieve. A topic should include two criteria to become an SSI: (i) the topic should be connected to science content and (ii) have a social meaning and significance (Eastwood et al., 2012). Besides the fact that SSI includes current science topics, it is extremely important that these contents are relevant to the topics and that student interests and needs are satisfied with examples from daily life.

SSI also paves the way for students to have discussions in the process. Tatar and Adıgüzel (2019) described this situation as, "Socioscientific issues are controversial issues that include science-related social dilemmas and create socially contentious thoughts in the process and products of science." There are some topics that SSI should cover. These include issues that cause dispute in the society, (ii) are a problem waiting to be solved, (iii) are open to evaluation from different perspectives, (iv) cannot be concluded easily, (v) plus ethical and moral issues (Sadler, 2009; Sadler, 2011; Topçu, 2019). There is a dynamic relationship between science and society. This relationship could be one of the factors that increase the welfare level of societies.

Social changes take place in the light of new information obtained through scientific studies. On the other hand, social changes also cause changes in educational sciences and alterations in understanding. For example, with the development of an industrial society understanding after World War II, formal education institutions gained significance, and system changes were made in education. After the 1960s, different needs arose from the industrial societies with technological developments, and the existing education system was changed once again (Karaman, 2014, p.1136). In the nineties, with the inclusion of environment (STSE) into Science, Technology, and Society (STS), it began to be considered as a new approach by researchers. In the 2000s, with cloning, genetic studies, global warming, and renewable energy studies, researchers have largely focused on studies conducted within the scope of SSI. For the first time, in 2013, the SSI was included in the science and technology curriculum, which also continued to remain in the 2018 curriculum (Topçu, 2019). In the ninth item, under the heading of special purposes of the science curriculum, "developing reasoning ability, scientific thinking habits and decision-making skills using socioscientific topics" has been included as a special purpose (MEB, 2018, p.9). One could argue that the inclusion of SSI in the curriculum is important for students to approach social problems more consciously and engage in current discussions with a scientific perspective.

Discussions on developing and changing social life and SSI are also encountered frequently in both social media and the written and visual media. For example, many discussions are being held about the nuclear power plant being built in our country, and 
students have been witnessing these discussions, too. On the other hand, organ donation, GMO products, and the pandemic period plus vaccines and different vaccine technologies are often featured in both written and visual media. It has also been seen recently that the news on these issues contains a lot of information pollution that could be considered as a fake or pseudoscience phenomenon. When we consider it from a holistic point of view, the importance of teaching SSI in schools becomes evident once again. SSI covers social dilemmas with conceptual or technological connections (Sadler, 2004). The needs of individuals and therefore societies are also changing along with the developing technology. In the program development process, the programs are being revised and renewed in line with the needs of the individual, society, and the subject area. Therefore, possibilities should be created for including SSI in the science curriculum, updating it according to the changing needs, and discussing SSI within the course contents.

The entire SSI contains discussions, but not every topic containing discussion can be considered as SSI (Sadler \& Zeidler, 2005a). When creating learning environments with SSI, students need to present and discuss evidence-based arguments. SSI allows students to engage in dialogue, discussion, and debate with each other; while doing this, ethical and moral rules should also be considered in solving possible problems in this process (Zeidler \& Nichols, 2009). It is one of the components of scientific literacy that students present evidence as a result of discussions and put forward solutions to the issues (Sadler \& Zeider, 2005b). In other words, one could say that the argumentation-based SSI improves the scientific literacy of students.

Zeidler and Nichols (2009) maintain that teachers are the primary element in encouraging students to think about alternative evidence-based arguments, underlining the importance of explaining the teacher, student, and content roles in SSI instruction, pedagogical expectations when guiding the research, and providing guidance when managing the match between students in the debate process. In the same study, they stated that students had unique experiences in the moral reasoning process while carrying SSI from theory to practice. However, in terms of content, the SSI presented to students allows them to reason and discuss by accessing scientific and non-scientific data from different sources. Argumentation used in SSI instruction could be defined as a process in which students make claims, justify their claims, reason and reach a decision, and use different models (like $5 \mathrm{E}$ ) based on a constructivist approach. In the literature, studies are showing the 5E method is also suitable for SSI teaching (Durmaz \& Karaca, 2019; e.g., Sickel et al., 2013), and studies suggesting that the $5 \mathrm{E}$ model supports SSI (Friedrichsen et al., 2016).

\section{Importance of Study}

Considering the literatüre, mixed-method and quasi-experimental studies existed on SSI teaching. In the mixed-research methods, however, the quantitative parts were mostly quasi-experimental (e.g., Deveci, 2009; Domaç, 2011; Kürkan, 2019; Yılmaz et al., 2019). While the sample is formed using a random assignment method in true experimental designs, the internal and external validity of the study cannot be fully satisfied because there is no random assignment in the quasi-experimental design (Can, 2019, p.14). Thus, the validity and reliability of quasi-experimental designs are lower than true experimental designs, but they are the most preferred designs in social sciences. There are studies in the literature on SSI, designed using a quasi-experimental design and grounded on constructivist approaches (Goloğlu, 2009; Gülhan, 2012; Pehlivan, 2020; Şahintürk, 2014). Most of these studies focused on the effects of SSI-based instruction on academic achievement, content knowledge, scientific literacy, and decision-making skills (Atabey, 2016; Deveci, 2009; Durmaz \& Karaca, 2019; Ergunt, 2019; Gülhan, 2012; Taşpınar, 2011; Topaloğlu, 2016). However, studies conducted in recent years have focused on the views of students and teachers and the use of SSI in the classroom and 
curriculum (Kara, 2015). Özcan and Kaptan (2019) examined the studies carried out between 2008 and 2017 and found that most studies were carried out with prospective teachers as a sample and the study themes were argumentation and knowledge level. There are also studies in the literature that examine the theses written in Turkey (Tatar \&Adıgüzel, 2019; Yapıcı̆̆lu \& Atabey, 2020).

It is stated that studies on SSI are mostly at a quantitative level and that more indepth qualitative studies should be conducted (Topçu et al., 2014). As a result of their research, Tezel and Günister (2018) reported that questionnaires have been used the most as a data collection tool in studies on socioscientific issues in Turkey. In studies conducted to determine how SSIs affect student achievement, many findings indicate that these practices increase student achievement (Brush et al., 2021; Şahintürk, 2014; Şeçkin Karaca, 2018; Khajornkhae \& Nuangchalerm, 202 1; Kürkan, 2019; Durmaz \& Seçkin Karaca, 2019; Sadler, Romine, \&Topçu, 2016).

Many studies have determined that SSI improves students' decision-making abilities (Gutierez, 2015; Topaloğlu, 2016), increases their argumentation quality (Akbaş \& Çetin, 2018; Yapıcıŏlu \& Kaptan, 2018), and maximizes their academic achievement (Şahintürk, 2014). On the other hand, there is a study in the literature determining that SSI- based instruction did not make a significant difference in favor of the experimental group when compared to the control group (Şengül 2017). This situation shows that there is a contradiction in the literature regarding the effect of socioscientific issues-based teaching on academic achievement. For this reason, in this study, a meta-analysis study was conducted in order to resolve this contradiction in the literature on academic achievement and to make theoretical and methodological suggestions for future studies.

Secondary studies (content analysis) also exist in the literature, which are different from the primary research. For example, Genç and Genç (2017) performed a content analysis of studies conducted on SSI in Turkey, in which they examined 36 articles. They found that only one study was conducted between 2000 and 2001, but none between 2002 and 2004. They stated that most studies were carried out in 2012. In a similar vein, Yapıcıoğlu and Atabey (2020) examined dissertation studies carried out between 2008 and 2018 containing SSI. They determined that most of these studies were carried out at the master's level, and quantitative research methods and quasi-experimental designs were employed often. However, these content analysis studies do not reveal whether socioscientific issues have an impact on the academic achievements of students. Therefore, this meta-analysis aims to see the effects of SSI on the academic achievement of students in Turkey and to help shape future studies on this subject. In line with this aim, responses were sought to the questions:

1. What is the effect of socioscientific issues-based instruction on academic achievement?

2. What are the views and experiences of students about socioscientific issues-based instruction?

3. What are the factors affecting the effectiveness of socioscientific issues-based instruction?

\section{Method}

A mixed-research synthesis method was used in this study. According to Sandelowski et al. (2006), mixed-research synthesis is a systematic literature review process that combines the results obtained from primary qualitative and quantitative studies. Mixed-research synthesis consists of three stages (Harden, 2010): (i) combining the quantitative research findings using a meta-analysis method, (ii) combining the qualitative research findings using a thematic synthesis method, and (iii) comparing the 
qualitative and quantitative syntheses results. The purpose of this method is to explain the variance between studies combined using the meta-analysis with the analytical themes derived from the thematic synthesis (Kanadl, 2020, p.94). In the meta-analysis method, fixed categories such as the school level, course type, program type, which are the characteristics of the studies, are used to determine the variance between studies. However, most of the time, these categories cannot explain the variance in a meaningful way. However, the analytical themes obtained from the thematic synthesis allow us to create new, previously unknown, categories specific to the study. This situation increases the probability of explaining the variance between studies. Therefore, mixed synthesis research method was preferred in this study.

\section{Data Collection Process/Literature Search}

Studies included in this research were retrieved from the Google Scholar, DergiPark, YOK Thesis Bank, and ERIC databases. Publish or Perish 7, a literature search program, was used for data collection. Initially, a search was performed on Google Scholar with key concepts to access studies on socioscientific issues. Studies found by the researchers were compared in certain time periods and different search strategies were developed. The Google Scholar was searched using "sosyobilimsel konular", "socioscientific issues", "fen" AND "sosyo bilimsel konular*", "controversial issues", "tartışmalı konular", and "toplum bilim konuları" concepts and 250 results were found. In the meta-analysis process, 61 studies were accessed from these results. YOK thesis was searched using the "socioscientific issues" and "sosyo bilimsel konular" concepts and 53 theses were accessed. Key concepts were searched using the Publish or Perish 7 program, and the studies conducted in Turkey were rechecked through Google Scholar and EBSCO, in an attempt not to miss any publication. In addition, Turkish theses and articles in the reference lists of content analysis studies were checked one by one. Of these records, 148 included socioscientific issues.

\section{Inclusion and Exclusion Criteria}

Since a mixed-research synthesis method was employed in this research, two separate inclusion criteria were used for meta-analysis and thematic synthesis studies. For studies to be included in the meta-analysis should the following criteria, (i) conducted between 2005 and 2020 in science, (ii) the effect of socioscientific issues on student achievement (level of knowledge, subject area, and content knowledge), and decisionmaking skills, (iii) experimental design, (iv) quantitative data in studies to compute effect sizes, and (v) use parametric statistical methods. Here, the reason for considering 2005 as the starting date of publications was the articulation of science, technology, society, and environment (STSE) subjects in the 2005 science curriculum. However, studies included in the thematic synthesis should meet the following criteria, (i) conducted between 2005 and 2020 in science, (ii) obtain the views of people participating in studies on socioscientific issues, and (iii) the researcher directly quotes views or statements from participants and reports the codes and themes.

As a result of the data search process, 250 records were reached. Of these records, 148 included socioscientific issues. Primarily, studies were sorted by subject titles, and the socioscientific issues were organized by academic achievement and decision-making skills. For instance, studies were sorted as opinions (1 study), textbook (2 studies), and subject areas (15 studies such as GMO, HPP, Nuclear Energy, Organ Donation, and renewable energy), and efforts were made to perform the readings and examinations more systematically. According to this, 66 studies were examined in terms of suitability. Of these studies, 32 were not included in the meta-analysis for being non-experimental and using non-parametric tests. The methods sections of the remaining 34 studies were read 
within two weeks, and the number of studies was reduced to 18 after their re-evaluation as a result of the online meetings of the two researchers.

\section{Figure 1}

Prisma flow diagram (Moher et al., 2009).

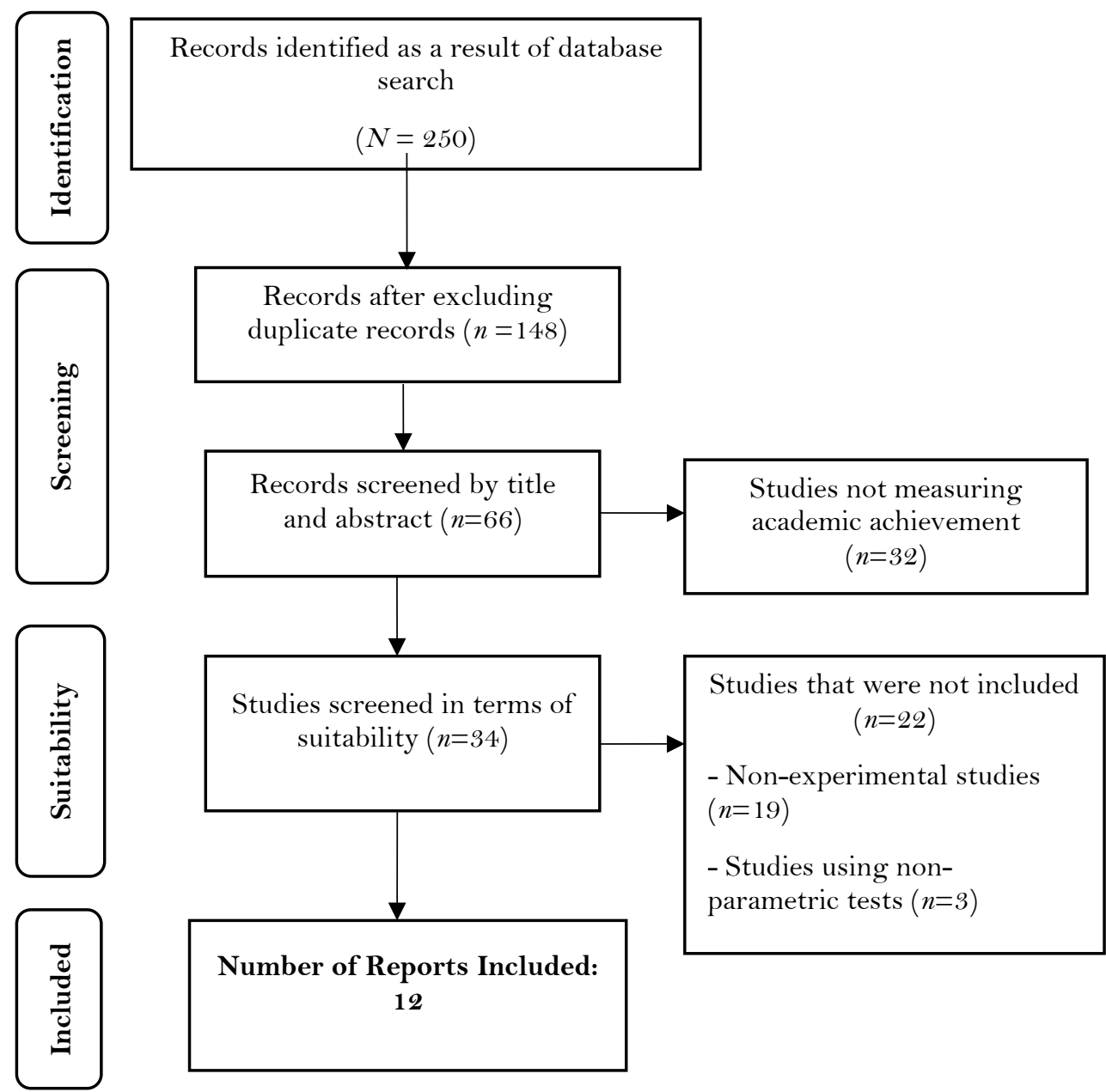

The remaining 18 studies were reread within a two-week time, and six more studies were not included in the meta-analysis for not reporting clear statistical operations, providing parametric and non-parametric statistics together and presenting non-parametric statistics for achievement, and un-understandability of the changes in groups. As a result, 12 studies experimentally applying socioscientific issues were included in the meta-analysis process. Conference papers, surveys, and studies using nonparametric statistical methods were not included in the meta-analysis. In the thematic synthesis process, however, the views obtained from the participants who were not involved in the process were excluded. Moreover, qualitative studies and the views in the qualitative parts of studies with mixed-research designs were included in the thematic synthesis.

In this meta-analysis study, revealing the effect of socioscientific issues on student achievement, 12 studies were included in the analysis. The total number of students in the studies included was 637. Moreover, 360 students were the experimental group students and 227 were the control group students. Table 1 presents the the percentage frequency values relating to the types of experimental studies, the education level in which the study was conducted, the subject area studied, the type of tests used in the study, and the publication type. 
Table 1

Descriptive statistics relating to the study variables

\begin{tabular}{lcc} 
Variables & Frequency (f) & Percentage (\%) \\
\hline Education Level & 2 & 16.67 \\
Primary School & 8 & 66.66 \\
Secondary School & 2 & 16.67 \\
Higher Education & 11 & \\
Type of Lesson & 1 & 91.67 \\
Science & & 8.33 \\
Social Studies & 2 & \\
Type of Design & 10 & 16.67 \\
Experimental & & 83.33 \\
Quasi-experimental & 12 & 100 \\
Test Type & 10 & 83.33 \\
Parametric & 2 & 16.67 \\
Publication Type & & \\
Thesis & & \\
Article & & \\
\hline
\end{tabular}

According to Table $1,66.66 \%(f=8)$ of studies included in the meta-analysis were conducted in secondary schools, $16.67 \%(f=2)$ in higher education, and $16.67 \%(f=2)$ in primary schools. Moreover, $91.67 \%(f=11)$ of studies addressing SSI were carried out in science and $8.33 \%(f=1)$ in social studies lessons. Considering the types of study designs, 83.33\% $(f=10)$ were quasi-experimental and $16.67 \%(f=2)$ were experimental. Some studies were conducted using mixed-research methods, and experimental ones were included in the study. As seen in the table, studies with parametric tests were included in the research. Finally, a total of 12 studies were included in the research, including $83.33 \%$ $(f=10)$ theses and $16.67 \%(f=2)$ articles.

\section{Quality Assessment of Studies}

After determining the inclusion and exclusion criteria in studies, the quality of studies was determined to prepare the coding form. Including studies of poor quality in research synthesis may affect the reliability of the results (Kanadlı, 2019, p.12). Therefore, a system developed by Pluye et al. (2009) for methodological quality assessment of qualitative and quantitative studies in health sciences was used. This assessment consists of four sections, i.e., qualitative, quantitative experimental, mixed, and quantitative descriptive. If a specified feature is present in the study, it gets a score of " 1 " or else gets "O". After that, the quality score is computed using the [(Number of criteria that exist) / (Total number of criteria) ]*100 formula. However, since studies in social sciences sometimes could partially meet a quality indicator, one could also give a score of 0.5. In this study, two criteria for quantitative experimental and mixed-methods studies were considered and the quality score was computed using the (total score received / 2 ) 100 . 
Since no percentage value for the quality score was known in the literature, studies with a score above $50 \%$ were included in the analysis in this study.

To determine the quality of studies included in the thematic synthesis, a "thematic synthesis quality scale" consisting of 12 questions was used (Harden, 2010). The scale includes items about the processes ranging from whether studies report purposes to confirming the interview transcripts with the participants. Studies meeting seven of these items were included in the thematic synthesis. Eighteen studies were retrieved as a result of the literature search performed on databases like Google Scholar, YOK Thesis Bank, and DergiPark. Six of these studies were evaluated as mixed-research methods and twelve as qualitative studies using the scale, and ten studies were included in the thematic synthesis. Three of the ten included studies were also included in the meta-analysis.

\section{Data Extraction}

Two separate coding forms were prepared for coding the qualitative studies. In the first coding form, studies were coded by author names, publication date, dependent variables (achievement, decision-making, and knowledge level), research design (mixed, experimental, quasi-experimental, weak experimental), sample characteristics (sample size, grade level, education level), measurement tools (achievement test, content knowledge test), data analysis test (parametric, non-parametric), and intervention features (application duration, course type, subject area), using a Word document. To extract the quantitative data according to inclusion criteria, a second form was prepared as an Excel document. In this coding form, author names, publication dates, posttest mean scores, standard deviations, sample sizes, and when these data were missing, independent samples $\mathrm{t}$ values and sample sizes, $\mathrm{F}$ tests and sample sizes were collected. Since parametric tests were included in the research, no data entry was performed for non-parametric tests. For qualitative data, however, directly quoted codes/category tables, containing the opinions and experiences of prospective teachers and secondary school students on socioscientific topics, were used.

\section{Data Analysis}

A meta-analysis method was employed to determine the effectiveness of experimental processes related to the teaching of socioscientific issues. As the sample sizes of experimental and mixed studies included in the meta-analysis were less than 20 in one study, Hedges's g was used as an effect size index. Since the studies were collected from the literature, the common effect was computed under a random-effects model (Borenstein et al., 2009, p.86). The effect sizes were interpreted according to Cohen et al.'s (2007, p.521) classification. Accordingly, the computed effect size could be interpreted as "weak" if it is 0-0.20, "small" if 0.2 1-0.50, "moderate" if 0.5 1-1.0, and "strong" if larger than 1.0,

A heterogeneity test was performed to determine the presence and size of variance between effect sizes. The size of heterogeneity was interpreted according to the $\mathrm{I}^{2}$ index, where an $\mathrm{I}^{2}$ of $25 \%$ is evaluated as small, $50 \%$ as medium, and $75 \%$ as high heterogeneity (Higgins, Thompson, Deeks, \& Altman, 2003). To determine whether there was a publication bias in the studies, the funnel plot of the theses and articles was examined and the Egger's Regression Intercept Test, Begg and Mazumdar Correlation Test, and Rosenthal's Fail N test were performed. CMA (version 2) and R package programs were used in analyzing the quantitative data. In the analysis of qualitative data, the data collected from the literature were entered into the QDA Miner Lite program. While entering the data, the codes in each study were extracted and entered into the program. The directly quoted codes were interpreted by the researchers. Further, the coding of the quantitative and qualitative data was conducted separately by two researchers and the reliability between the coders was computed as $100 \%$. 


\section{Findings}

\section{Meta-Analysis}

A forest plot of effect sizes from 12 studies included in the meta-analysis study is given in Figure 1.

\section{Figure 2}

Forest plot of the effect sizes of the study

\section{Study}

1. Tașpınar, 2010

2. Deveci, 2009

3. Şahintürk, 2014

4. Kutluca, 2016

5. Şengül, 2017

6. Seçkin, 2018

7. Kürkhan, 2019

8. Pehlivan, 2020

9. Domaç, 2011

10. Özcan, 2019

11. Topaloğlu, 2016

12. Zengin, 2012

\section{Hedges g $[95 \%-\mathrm{Cl}]$ zval P-value}

$\begin{array}{lr}0.594[0.026 ; 1.162] 2.048 & 0.04 \\ 0.429[-0.002 ; 0.860] 1.950 & 0.05 \\ 0.856[0.384 ; 1.328] 3.552 & <0.01 \\ 2.123[1.474 ; 2.772] 6.414 & <0.01 \\ 0.294[-0.500 ; 1.088] 0.726 & 0.47 \\ 0.919[0.351 ; 1.487] 3.169 & <0.01 \\ 1.646[0.964 ; 2.328] 4.730 & <0.01 \\ 0.467[0.057 ; 0.877] 2.234 & 0.03 \\ 1.398[0.857 ; 1.939] 5.065 & <0.01 \\ 0.747[0.186 ; 1.308] 2.612 & <0.01 \\ 2.775[1.840 ; 3.710] 5.818 & <0.01 \\ 1.264[0.701 ; 1.827] 4.404 & <0.01\end{array}$

Random effects model 1.076 [ $0.724 ; 1.428]$

Heterogeneity: $I^{2}=78 \%, \tau^{2}=0.2942, \chi_{11}^{2}=50.77(p<0.01)$

Test for overall effect: $z=5.99(p<0.01)$

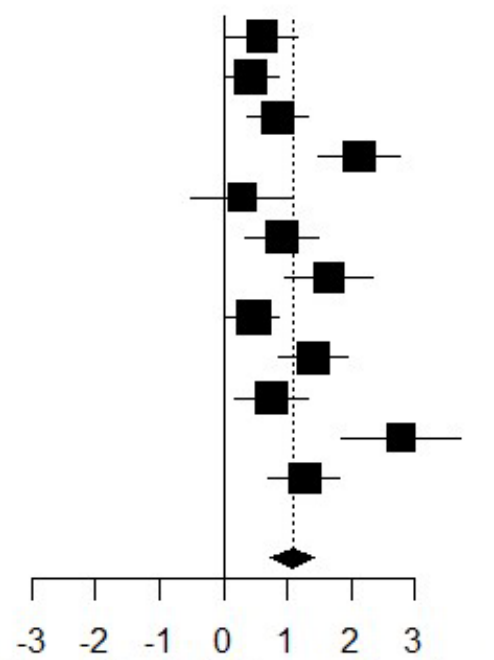

Favors Control Favors Experiment

As illustrated in Figure 2, one of the studies (8.33\%) yielded a non-significant effect size. Eleven studies (91.67\%) yielded significant effect sizes. According to the forest plot, Deveci's (2009) dissertation study has the smallest effect size (ES=0.429), and Topaloğlu's (2016) dissertation study had the largest. According to Cohen et al.'s (2007) classification, $25 \%(f=3)$ of studies had small, $33.3 \%(f=4)$ had moderate, and $41.7 \%(f=5)$ had strong effect sizes. When the studies were combined according to the random-effects model, the overall effect size was 1.076 , with a lower limit of 0.724 and an upper limit of 1.428. As seen in the plot, the common effect size was significantly different from zero $(\mathrm{z}=5.992$, $\mathrm{p}<0.01)$. According to Cohen et al. (2007), this effect size is strong. As per this finding, one could argue that socioscientific-based instruction has a strong effect on student achievement. The heterogeneity test conducted to determine the presence and size of the variance between studies was significant $\left(Q_{(1)}=50.77, p<.01\right)$. According to Higgins et al. (2003), the size of the variance was "high". This finding indicates that studies do not share a common effect, and therefore other variables also contribute to the variance besides the sampling error. Categorical moderator analysis was conducted to determine these variables. Hence, studies included in the meta-analysis were classified according to school level (primary, secondary, and university) and applied program (FESKÖK, Science curriculum). The categorical moderator analyses of these classifications are given in Table 2 .

As seen Table 2, school type is a significant moderator. Accordingly, one could argue that socioscientific issues-based instruction has the highest effect on the academic achievement of university students. Similarly, it seems that the curriculum containing socioscientific issues makes a significant contribution to the variance. Accordingly, the effect size value of studies conducted within the scope of the national science curriculum was higher than those carried out according to the curriculum developed for teaching 
socioscientific issues. In short, one could argue that the curriculums developed for teaching socioscientific issues in the literature have a smaller effect on student achievement compared to the current science curriculum.

Table 2

Moderator analysis results

\begin{tabular}{|c|c|c|c|c|c|c|c|}
\hline \multirow[b]{2}{*}{ Moderators } & \multirow[b]{2}{*}{$\boldsymbol{k}$} & \multirow[b]{2}{*}{$\begin{array}{l}\text { Effect } \\
\text { Size }\end{array}$} & \multicolumn{2}{|c|}{$95 \% \mathrm{CI}$} & \multicolumn{3}{|c|}{ Heterogeneity } \\
\hline & & & $\begin{array}{l}\text { Lower } \\
\text { Limit }\end{array}$ & $\begin{array}{l}\text { Upper } \\
\text { Limit }\end{array}$ & $O b$ & $d f$ & $p$ \\
\hline School Level & 12 & 0.961 & 0.690 & 1.232 & 6.67 & 2 & 0.035 \\
\hline Secondary & 2 & 0.672 & 0.272 & 1.071 & & & \\
\hline High-school & 8 & 1.012 & 0.580 & 1.443 & & & \\
\hline University & 2 & 1.737 & 1.028 & 2.446 & & & \\
\hline Prog. type & 12 & 0.796 & 0.531 & 1.061 & 8.32 & 1 & 0.004 \\
\hline FESKÖK & 2 & 0.431 & 0.067 & 0.794 & & & \\
\hline $\begin{array}{l}\text { Science } \\
\text { curriculum }\end{array}$ & 10 & 1.212 & 0.825 & 1.600 & & & \\
\hline
\end{tabular}

\section{Publication Bias}

Publication bias is that studies with higher effect sizes are more likely to be published than studies with lower effect sizes (Borenstein et al., 2013, p.267). One of the methods suggested for determining the publication bias is conducting a categorical moderator analysis by classifying studies included in the meta-analysis as published/unpublished (thesis/article; Card, 2012, p.262). As a result of the analysis, when there is no significant difference between the studies according to the publication status, we could claim that there is no publication bias. As a result of the categorical moderator analysis conducted for this purpose, effect sizes did show significant differences considering the publication status (thesis/article; $Q(2)=0.078, p>.05$ ).

To determine the presence of publication, the funnel plot was examined, and other diagnostic tests were performed (Duval and Tweedie's Trim and Fill, Begg and Mazumdar Rank Correlation, Egger's Intercept Test, and Rosenthal's Fail-Safe N). As illustrated in the funnel plot, the effect sizes did not form symmetry in the middle and around the overall effect size within the limits drawn in the funnel plot. According to the funnel plot, one may conclude that there is a publication bias. To understand precisely whether there is a publication bias, Duval and Tweedie's Trim and Fill method was tested. Accordingly, both the observed and expected effect sizes were computed as $1.076,95 \% \mathrm{CI}$ $[0.7241,1.4278)$. As these two effect sizes are equal, one could contend there is no publication bias. Similarly, Begg and Mazumdar Rank Correlation and Egger's Intercept tests results were non-significant at a 95\% confidence level $(p>0.05)$. These results indicate that the asymmetry observed in the funnel plot does not stem from the publication bias.

Lastly, Rosenthal's Fail-Safe $\mathrm{N}$ was examined to understand how strong the computed common effect size was. As per the results of this test, it was computed that how many studies with zero effect sizes were required for the common effect to become non-significant. As per the results of the analysis, while the number of observed studies was 11,344 studies with zero effect sizes were required to make the effect size nonsignificant. According to Rosenthal (1979), when the number of studies needed is five times the number of the observed studies plus ten, we could say that there is no publication bias. Given that the threshold value for the meta-analysis study was $(5 \times 11+10) 65$ and 
that this threshold value was exceeded considering the results (344 studies), one could argue that there is no publication bias and the observed effect size is robust.

\section{Figure 3}

Funnel Plot



\section{Thematic Synthesis}

Six studies with qualitative findings with medium and high-quality scores were included in the thematic synthesis. The qualitative findings of these studies, in other words, the direct quotations in the findings or the researchers' code definition tables were extracted and entered into QDA Miner Lite, a qualitative data analysis software. In the first stage of the thematic synthesis, the qualitative data entered into the program were read and coded line-by-line. In the second stage, the codes whose definitions were close to each other were combined under the same theme by expanding the code definition.

As a result of the thematic analysis of the studies conducted on SSI, the emerging themes and their codes were extracted. In the theme, characteristics that teachers and prospective teachers should have, the following codes were common: they should (i) be curious, (ii) researcher, (iii) open-minded, (iv) solution-oriented, (v) have students do practical activities in the lesson, (vi) address current issues (vii), and the educator should be equipped. Moreover, the theme of SSI Learning Outcomes included codes such as (i) provides with affective skills, (ii) fulfills concrete learning, (iii) heightens motivation, (iv) fulfills meaningful and complete learning, $(v)$ provides opportunities for application, (vi) facilities remembering, (vii) provides with decision-making skills, (viii) improves higherorder thinking skills, (ix) encourages teamwork, and $(x)$ improves decision-making skills. However, the codes under the theme of limitations in SSI Instruction were (i) insufficiency of time in science classes, (ii) student age and readiness level, (iii) student prejudices, and (iv) the lack of teacher knowledge. Further, there were some recommendations regarding the process of teaching SSI subjects. The codes under the theme of recommendations included (i) out-of-class activities should be conducted, (ii) the number of SSI learning outcomes should be increased, (iii) The should be a separate subject in the curriculum, (iv) The number of topics should be increased in the curriculum, (v) Should be included more 
in the books, (vi) Teachers should be given training, (vii) practical activities should be conducted, and (viii) students should be allowed to have discussions. These recommendations may affect teaching the SSI topics and the learning outcomes.

Table 3

The application status of the analytical themes in studies included in the meta-analysis*

\begin{tabular}{|c|c|}
\hline Analytical Themes & Studies Applying the Recommendation \\
\hline $\begin{array}{l}\text { 1. SSI should be taught } \\
\text { after primary school. }\end{array}$ & $\begin{array}{l}{ }^{2} \text { Deveci, 2009; }{ }^{9} \text { Domaç, } 2011 \text {; }{ }^{12} \text { Zengin, 2012; }{ }^{3} \text { Şahintürk, } \\
\text { 2014; }{ }^{4} \text { Kutluca, 2016; }{ }^{5} \text { Şengül, } 2017 ;{ }^{8} \text { Pehlivan, 2020; } \\
{ }^{11} \text { Topaloğlu, 2016; }{ }^{6} \text { Seçkin Karaca, 2018; }{ }^{7} \text { Kürkan, 2019; }\end{array}$ \\
\hline $\begin{array}{l}\text { 2. Students should be } \\
\text { allowed to have discussions } \\
\text { during SSI instruction. }\end{array}$ & $\begin{array}{l}{ }^{2} \text { Deveci, 2009; }{ }^{1} \text { TaŞpınar, } 2011 ;{ }^{12} \text { Zengin, } 2012 ;{ }^{10} \text { Yılmaz } \\
\text { Özan and Tabak, 2019; }{ }^{3} \text { Şahintürk, 2014; }{ }^{4} \text { Kutluca, } 2016 \text {; } \\
{ }^{5} \text { Şengül, 2017; }{ }^{8} \text { Pehlivan, 2020; }{ }^{9} \text { Domaç, } 2011\end{array}$ \\
\hline
\end{tabular}

3. SSI instruction should ${ }^{11}$ Topaloğlu, 2016
be carried out in out-of-
class learning
environments.

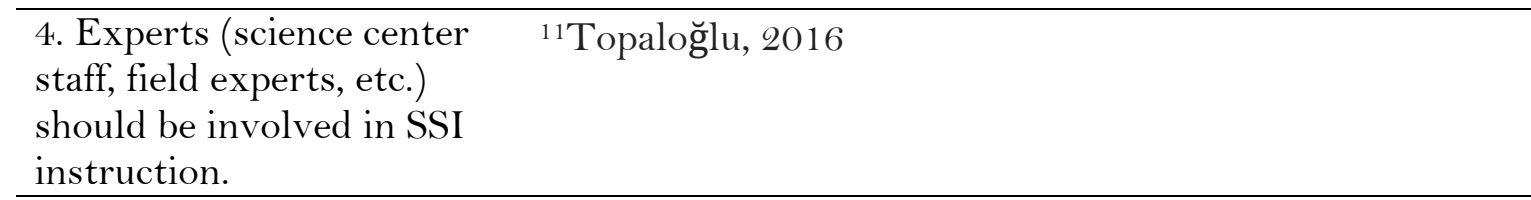

Teachers should receive ${ }^{8}$ Pehlivan, 2020; training on SSI.

6. A special curriculum $\quad{ }^{5}$ Şengül, 2017; ${ }^{8}$ Pehlivan, 2020; should be prepared for SSI.

*The superscript numbers in the table are the sequence order of studies in the forest plot.

In the third stage of the thematic synthesis, considering the descriptive themes they obtained by combining the codes, the two researchers discussed what kind of interventions should be carried out in teaching SSI and what the practitioners should take into account for SSI instruction to be more effective. As a result of discussions, the following hypotheses (analytical themes) emerged:

1. SSI should be taught after primary school.

2. Students should be allowed to have discussions during SSI instruction.

3. SSI instruction should be carried out in out-of-class learning environments.

4. Experts (science center staff, field experts, etc.) should be involved in SSI instruction.

5. A special curriculum should be prepared for SSI.

6. Student age should be taken into consideration. 
Table 4

The results of the moderator analysis of the studies included in the meta-analysis according to the application status of the analytical themes

\begin{tabular}{|c|c|c|c|c|c|c|c|}
\hline \multirow[b]{2}{*}{ Moderator No } & \multirow[b]{2}{*}{$k$} & \multicolumn{2}{|c|}{$95 \% \mathrm{C}$} & \multirow[b]{2}{*}{$\begin{array}{c}\text { Upper } \\
\text { Lim. }\end{array}$} & \multicolumn{3}{|c|}{ Heterogeneity } \\
\hline & & $\begin{array}{c}\text { Effect } \\
\text { size }\end{array}$ & $\begin{array}{c}\text { Lower } \\
\text { Lim. }\end{array}$ & & $Q b$ & $d f$ & $p$ \\
\hline Analytic Theme 1 & 12 & 0.909 & 0.620 & 1.197 & 2.828 & 1 & 0.093 \\
\hline Applied & 10 & 1.167 & 0.750 & 1.584 & & & \\
\hline Not Applied & 2 & 0.672 & & & & & \\
\hline Analytic Theme 2 & 12 & 0.990 & 0.661 & 1.319 & 2.402 & 1 & 0.121 \\
\hline Applied & 9 & 0.897 & 0.548 & 1.246 & & & \\
\hline Not Applied & 3 & 1.721 & 0.739 & 2.704 & & & \\
\hline Analytic Theme 3 & 12 & 1.141 & 0.845 & 1.438 & 13.049 & 1 & $0.000^{*}$ \\
\hline Applied & 1 & 2.775 & 1.841 & 3.710 & & & \\
\hline Not Applied & 11 & 0.959 & 0.646 & 1.271 & & & \\
\hline Analytic Theme 4 & 12 & 1.141 & 0.845 & 1.438 & 13.049 & 1 & $0.000^{*}$ \\
\hline Applied & 1 & 2.775 & 1.841 & 3.710 & & & \\
\hline Not Applied & 11 & 0.959 & 0.646 & 1.271 & & & \\
\hline Analytic Theme 5 & 12 & 0.833 & 0.557 & 1.110 & 5.687 & 1 & $0.017^{*}$ \\
\hline Applied & 1 & 0.467 & 0.058 & 0.875 & & & \\
\hline Not Applied & 11 & 1.141 & 0.767 & 1.516 & & & \\
\hline Analytic Theme 6 & 12 & 0.796 & 0.531 & 1.061 & 8.321 & 1 & $0.004^{*}$ \\
\hline Applied & 2 & 0.431 & 0.067 & 0.794 & & & \\
\hline Not Applied & 10 & 1.212 & 0.825 & 1.600 & & & \\
\hline
\end{tabular}

\section{Integrating the Meta-Analysis and Thematic Synthesis}

To understand whether the analytical themes (hypotheses) derived from the thematic synthesis are applied in experimental and mixed-method studies, these studies were reexamined by the two researchers. The results of the analysis regarding the analytical themes are given in Table 3. SSI instruction in two studies has been carried out at the primary school level, and the remaining ten studies were carried out at the secondary school and university levels $2,3,4,5,6,7,8,9,11,12$. Nine studies included argumentation-based discussions in SSI instruction 1, 2, 3, 4, 5, 8, 9, 10, 12. However, only in one of the studies included in the meta-analysis, SSI instruction was performed in out-of-class learning environments ${ }^{11}$. Likewise, there was only one study in which experts were involved in SSI instruction ${ }^{11}$. In one study, teachers received pre-application training on $\mathrm{SSI}^{8}$. In two of the studies included, a special curriculum/program was prepared for SSI topics ${ }^{5,8}$.

As seen in Table 4, four (analytical themes 3,4, 5, and 6) out of six analytical themes derived from the thematic synthesis significantly accounted for the between-study variance $(\mathrm{p}<0.05)$. Accordingly, the mean effect of studies that implemented SSI instruction in out-of-class learning environments was $2.775,95 \%$ CI [1.841, 3.710], whereas the mean effect size of in-class applications was $0.959,95 \%$ CI [0.646, 1.271]. As per this finding, providing out-of-class education in SSI instruction could be impactful in increasing the academic achievement of students. According to the table, the effect size of the study in which the experts explained the topic during the out-of-class trips was 2.775 , $95 \%$ CI $[1.841,3.710]$, while the effect size of the studies in which teachers directed the lesson instead of the experts was $0.959,95 \%$ CI [0.646, 1.271]. As per these findings, the academic achievement of students may increase evermore when out-of-class instruction takes place by field experts. While the effect size of studies that prepared a curriculum for 
SSI was $1.212,95 \%$ CI $[0.825,1.600]$, the effect size of studies following the normal curriculum was $0.431,95 \%$ CI $[0.067,0.794]$. According to these findings, preparing a curriculum for SSI teaching might increase the academic achievement of students.

The third hypothesis could be expressed as in the following: "As the age of the students increases, the effect of socioscientific issues on academic achievement increases." Therefore, it could be analyzed as a continuous variable, not as a categorical one. Thus, a meta-regression analysis was performed. As a result of the meta-regression analysis, the model tested to explain the increase in academic achievement with student age was nonsignificant under the random-effects $(Q=3.56, p>.05)$. According to this result, there is no significant relationship between the age of students and their academic achievement.

\section{Discussion And Conclusion}

\section{Summary of the Principal Findings}

This study aimed to see the effects of SSI on the academic achievement of students in Turkey, to identify factors affecting practices relating to SSI, and to assist in shaping future studies by synthesizing the results of studies with qualitative and quantitative findings. Therefore, data obtained from 12 quantitative and 6 qualitative studies were used. The findings of the quantitative studies included in the study were analyzed using a meta-analysis method. Data extracted from studies with qualitative findings were combined using a thematic synthesis method. Further, it was attempted to explain the variance between studies included in the met-analysis by using the analytical themes obtained from the thematic synthesis.

The 12 studies included in the meta-analysis were combined under a randomeffects model. The reason for combining according to this model was that the studies were collected from the literature (Borenstein et al., 2009). As a result of combining, the common effect size was computed as $1.076,95 \%$ CI $[0.724,1.428]$. The computed common effect size was significantly different from zero $(z=5.992, p<.05)$. According to effect size classification, this value could be interpreted as a strong effect size. Accordingly, SSI instruction has a strong effect on the academic achievement of students.

Furthermore, the heterogeneity test performed to determine whether the studies included in the meta-analysis share the same common effect indicated that they were highly heterogeneous $\left(Q_{(11)}=50.78, p<.05, I^{2}=78 \%\right)$. To determine the reasons behind the variance between studies, moderator analyses were performed according to the school level (primary, secondary, and university) and the implemented program (feskök, normal science curriculum). As a result of the analysis, the SSI-based curriculum showed a significant difference according to the school level and the implemented curriculum. Accordingly, the effectiveness of SSI-based instruction increases if carried out at the university level and under the science curriculum.

Data from six studies containing qualitative findings included in the thematic synthesis were read in detail and coded. Codes created in the reading process were classified according to the similarities and differences. These codes were categorized under the following four themes: (i) Characteristics that teachers and prospective teachers should have, (ii) SSI learning outcomes, (iii) Limitations in SSI instruction, and (iv) Recommendations regarding the SSI instruction process. According to the themes, the educators should be learning guides who follow current issues, are curious, researcher, open-minded towards events and facts, solution-oriented, have a good grasp of their fields, and conduct practical activities in teaching-learning processes. As learning outcomes in SSI instruction, it was revealed that students' affective skills increase, learning takes place more concretely, high-order thinking skills improve in the learning process, meaningful and complete learning occurs through teamwork, and students' decision-making skills develop by doing practical activities. 
In addition to all these positive learning outcomes, there are also some limitations in SSI instruction. These limitations were determined to be insufficient lesson duration, student age and readiness levels, student prejudices, and lack of teacher knowledge about current issues. Students also recommendations regarding the SSI instruction. There were also recommendations from educators regarding SSI instruction. These suggestions were put forward in the form of teaching SSI subjects in out-of-class learning environments, increasing the number of topics and learning outcomes, including them under a separate subject in the curriculum, giving practical training to teachers, focusing more on practical activities in teaching lessons, and allowing students to have discussions during the lessons.

Six themes were obtained from the thematic synthesis. At least one of the identified themes relating to SSI instruction was used in quantitative studies. In the thematic synthesis, the third, fourth, fifth, and sixth themes were significant. Other themes were non-significant and the hypotheses related to the themes were rejected. Considering themes that yielded significant results, the third analytical theme suggested that SSI instruction should be carried out in out-of-class learning environments. The moderator analysis performed in relation to this theme yielded significant results. Accordingly, the study with out-of-class activities had a higher effect size compared to studies with in-class activities. It could be stated that interactive teaching in out-of-school environments like nuclear power plants, gene centers, and science centers are influential in increasing student achievement in SSI instruction.

The fourth analytical theme suggested that SSI instruction should be carried out by experts. The moderator analysis relating to this theme was also significant. The effect size of the study, in which the experts provided education in an out-of-school setting, was larger than the experimental studies in which the teacher did the course activities. This finding shows that the academic achievement of students may increase even more when the SSI instruction is supported by field experts. The fifth analytical theme suggested preparing a special curriculum for SSI instruction. The moderator analysis relating to this theme was also significant. According to this result, the effect sizes of two studies implementing a special curriculum in experimental activities were smaller than those of other studies. Lastly, the meta-regression analysis performed to understand the extent to which students' age levels were influential in SSI instruction turned out non-significant. The hypotheses relating to these themes were rejected.

\section{Comparison with Other Studies}

Although there are studies in the literature that report SSI has a positive effect on students' academic achievement (Durmaz \& Seçkin Karaca, 2019; Kürkan, 2019; Sadler, Romine, \&Topçu, 2016; Şahintürk, 2014; Şeçkin Karaca, 2018), some studies report nonsignificant effects (Şengül, 2017). As a result of the meta-analysis, it was determined that SSI-based instruction may have strong effect on the academic achievement of students. Therefore, one could argue that this meta-analysis resolved this conflict in the literature. The factors making SSI instruction effective were determined through a thematic synthesis method. Accordingly, teaching SSI in out-of-class learning environments and SSI instruction carried out by experts had a positive effect on SSI instruction. The SSI instruction carried out in out-of-class learning environments may have increased the level of knowledge of students and thus have increased their academic achievement. Topaloglu (2016) stated that the practices carried out in out-of-school learning environments are effective when students' do hands-on evaluations of positive and negative aspects in controversial SSI instruction. Dierking and Falk (2004) argue that out-of-school learning environments allow students to learn by doing. For prospective teachers to reflect meaningful learning in their lives, the SSI instruction process should be carried out by experiencing it (Türkmen et al., 2017). 
One of the other recommendations made as a result of the thematic synthesis is that experts should be involved in SSI instruction. Only one study applied this recommendation. The effect size of this study was greater than those of eleven studies not applying this recommendation. This finding indicates that experts are of great significance in SSI instruction. In cases where out-of-school teaching is not implemented, conducting SSI instruction by inviting experts to the classrooms may increase the effectiveness of teaching. In addition, it could be considered as an important factor that teachers and prospective teachers increase their subject knowledge in SSI and receive training for this purpose. Özcan and Kaptan (2020) suggested supporting teachers and prospective teachers with pre-service and in-service training to increase their competence in SSI.

Considering the literature, Ayvacs et al. (2019) examined the attitudes of prospective science teachers towards socioscientific issues according to their grade levels and determined that the highest attitude was at the fourth-grade level and the lowest at the second-grade level. Researchers interpreted the reason for this situation as the fact that none of the courses students received in the first grade include SSI. This result supports the proposition that the academic achievement of students increases in SSI instruction as their ages increase. Zeidler et al. (2003) emphasized the importance of personal and social aspects in increasing the comprehension of the SSI content and academic achievement. As such, personal experiences, social values, and the views of individuals might be influential in SSI instruction.

As a result of the thematic synthesis, another proposition predicted to be effective in SSI instruction is that a suitable curriculum should be prepared for SSI. This proposition turned out significant considering the meta-analysis result. Two studies applied this proposition, and their effect sizes were smaller compared to the effect sizes of studies that did not. A curriculum has been developed in the study, and education has been provided within the scope of this curriculum. Regarding this situation, Klosterman and Sadler (2010) argue that typically, when such curriculums are developed, there might be curriculums developed without the collaboration of teachers and without consulting the evaluation criteria of different audiences. The reason for this situation might be as stated by Klosterman and Sadler.

\section{Implication and Limitations}

According to the results obtained, the following recommendations can be made for practitioners in future studies: (i) SSI instruction should be carried out in out-of- class learning environments. (ii) Experts (science center staff, field experts, etc.) should be involved in SSI instruction. (iii) Teachers should receive training on SSI. (iv) A special curriculum should be prepared for SSI. (v) SSI-based education is more successful at university level than secondary and high school. Researchers may be advised to examine the effect of SSI-based instruction on higher-order thinking skills (critical thinking, creative thinking, problem solving), scientific process skills, and decision-making skills.

Attempting to explain the variance between the effect sizes computed through the meta-analysis with the help of the analytical themes obtained from the thematic synthesis and including only parametric tests in the study are the strong aspects of this study. However, there are also some limitations. These limitations may include that only 12 experimental studies were included in the study and the use of different teaching approaches, methods, and techniques to support SSI instruction. In addition, only one study applied the fourth analytical theme, which limits the generalizability of the result obtained. 


\section{About the Authors}

Cüneyt Akyol is a science teacher of gifted students. He is a $\mathrm{PhD}$ student at Mersin University, Faculty of Education, Curriculum and Instruction Department, Turkey. At the Science and Art Center, he guides gifted children to find solutions to their daily life problems. His research interests include STEM education and socioscientific issues. He also works on the integration of robots and sensors into education.

Sedat Kanadli is an Associate Professor at Mersin University, Turkey. Sedat Kanadlı received his $\mathrm{PhD}$ in Curriculum and Instruction from Gaziantep University. Dr. Kanadlı is a programme developer and instructional methods expert whose main research interests lie in the fields of curriculum development, meta research in education, science education, instructional processes and technologies, educational philosophy, and teachers' professional development. He has published many articles and books on these subjects.

\section{References $^{2}$}

Akbaş, M., \& Çetin, P. S. (2018). Üstün yetenekli öğrencilerin çeşitli sosyobilimsel konulara ilişkin argümantasyon kalitesinin ve informal düşünme becerisinin incelenmesi. Necatibey Eğitim Fakültesi Elektronik Fen ve Matematik Eğitimi Dergisi, 12(1), 339-360. https://doi.org/10.17522/balikesirnef.437794

Atabey, N. (2016). Sosyobilimsel konu temelli bir ünitenin geliştirilmesi: 7. sını öğrencilerinin konu alan bilgisi ve argümantasyon nitelikleri. [Yayımlanmamış Doktora Tezi]. Muğla Sıtkı Koçman Üniversitesi.

Ayvacı, H. Ş., Bülbül, S., \& Türker, K. (2019). Fen bilgisi öğretmen adaylarının sosyobilimsel konular hakkındaki tutumlarının sınıf düzeyine göre incelenmesi. Ondokuz Mayıs Üniversitesi Eğitim Fakültesi Dergisi, 38(2), 17-30. https://dergipark.org.tr/en/pub/omuefd/issue/50852/525453

Borenstein, M., Hedges, L. V., Higgins, J. P. T., \& Rothstein, H. R. (2013). Meta-analize giriş, (Çev.S.Dinçer). Anı Yayıncılık.

Brush, T., Glazewski, K., Shin, S., \& Shin, S. (2021). Implementation of a technologysupported socioscientific inquiry unit in high school biology: Impact on student achievement and attitudes. Journal of Computers in Mathematics and Science Teaching, 40(4), 303-330. https:// doi.org/10.14434/ijdl.v7i2.20124

Can, A. (2019). Spss ile bilimsel araştırma sürecinde nicel veri analizi (8th ed.) Pegem Akademi.

Card, N.A. (2012). Applied meta-analysis for social science research. Guilford Press.

*Deveci, A. (2009). İlköğ retim yedinci sını öğ rencilerinin maddenin yapısı konusunda sosyobilimsel argümantasyon, bilgi seviyeleri ve bilişsel düşünme becerilerini geliștirmek. [Yayımlanmamıș Yüksek Lisans Tezi]. Marmara Üniversitesi.

Dierking, L., \& Falk, J. H. (2004). Using a Behavior Change Model to Document the Impact of Visits to Disney's Animal Kingdom: A Study Investigating Intended Conservation Action. Curator: The Museum Journal, 47(3), 322343. https://doi.org/10.1111/j.2151-6952.2004.tb00128.x

Durmaz, H., \& Karaca, H. S. (2019). Sosyobilimsel konulara dayalı fen eğitiminin 7. sınıf öğrencilerinin sosyobilimsel konulara bakış açıları, bilimsel ve yansıtıcı düşünme becerileri üzerine etkisi. Anadolu Üniversitesi Eğitim Fakültesi Dergisi, 4(1), 21-49.

\footnotetext{
${ }^{2}$ Studies marked with asterisks (*) were included in the mixed-research synthesis.
} 
*Domaç, G. G. (2011). Biyoloji eğitiminde toplum bilimsel konuların öğ renilmesinde argümantasyon tabanlı öğ renme süreçlerinin etkisi. [Yayımlanmamış Yüksek Lisans Tezi]. Gazi Üniversitesi.

Eastwood, J. L., Sadler, T. D., Zeidler, D. L., Lewis, A., Amiri, L., \& Applebaum, S. (2012). Contextualizing nature of science instruction in socioscientific issues. International Journal of Science Education, 34(15), 2289-2315. https://doi.org/10.1080/09500693.2012.667582

Erkuş, A. (2013). Davranış bilimleri için bilimsel araştırma süreci (4th ed). Seçkin Yayınları.

Ergunt, E. (2019). Farklı bilgi kaynaklarindan edinilen bilgilerin sosyobilimsel konularda oluşturulan argümantasyonların kalitesi ve fen başarısı üzerindeki etkisi. [Yayımlanmamış Yüksek Lisans Tezi]. Hacettepe Üniversitesi.

Friedrichsen, P., Sadler, T., Graham, K., \& Brown, P. (2016). Design of a socio-scientific issue curriculum unit: Antibiotic resistance, natural selection, and modeling. International Journal of Designs for Learning, 7(1).

https://www.learntechlib.org/p/209612/

Genç, M., \& Genç, T. (2017). Türkiye'de sosyo-bilimsel konular üzerine yapılmış araştırmaların içerik analizi. E-Kafkas Eğitim Araştırmaları Dergisi, 4(2), 27-42. https://doi.org/10.30900/kafkasegt.291772

*Goloğlu, S. (2009). Fen eğ itiminde sosyo-bilimsel aktivitelerle karar verme becerilerinin geliştirilmesi: dengeli beslenme. [Yayımlanmamış Yüksek Lisans Tezi]. Marmara Üniversitesi.

Gutierez, SB (2015). Lise öğrencilerinin biyoetik karar verme becerilerini geliştirmek için sosyo-bilimsel sorunları bütünleştirmek. Uluslararası Eğitim Çalışmaları, 8(1), 142-151.

*Gülhan, F. (2012). Sosyo-bilimsel konularda bilimsel tartışmanın 8. sını öğ rencilerinin fen okuryazarlı̆̆ı, bilimsel tartışmaya ĕ̆ ilim, karar verme becerileri ve bilim-toplum sorunlarına duyarlılıklarına etkisinin araştırılması. [Yayımlanmamış Yüksek Lisans Tezi]. Marmara Üniversitesi.

Harden, A. (2010). Mixed-methods systematic reviews: Integrating quantitative and qualitative findings. A Publication of the National Center for the Dissemination of Disability Research (NCDDR): Technical Brief No.25. Retrieved from: https://ktdrr.org/ktlibrary/articles_pubs/ncddrwork/focus/focus25/Focus25.pdf

Herman, B. C., Clough, M. P., \& Rao, A. (2022). Socioscientific issues thinking and action in the midst of science-in-the-making. Science E education, 1-35. https://doi.org/10.1007/s11191-021-00306-y

Kanadlı, S. (2020). Sosyal bilimlerde teoriden uygulamaya araştırma sentezi (3rd ed.). Pegem Akademi.

Kara, Y. (2015). Kitap tanıtımı: Sosyobilimsel konular ve öğretimi. Uluslararası Sosyal ve Eğitim Bilimleri Dergisi, 2(4), 242-244.

https://doi.org/10.20860/ijoses.80140

Karaman, K. (2016). Hayat boyu öğrenme etkinliklerinde yerel yönetimlerin rolü. Journal of International Social Research, Research. 9. 1135-1142. https://doi.org/10.17719/jisr.20164420182

Khajornkhae, L., \& Nuangchalerm, P. (2021). Socioscientific-issues based classroom intervention on grade 10 students' learning achievement and scientific reasoning. Journal of Educational Issues. 7(2), 393-400.

https://doi.org/10.5296/jei.v7i2.19204 
Koca, F. (2019). Akademik öz-yeterlik ile akademik başarı arasındaki ilişkide sınav kaygısı ve akademik motivasyonun aracı rolü. Elementary Education Online, 18(1), 241-252. https://doi.org/10.17051/io.2015.85927

*Kürkan, E. I. (2019). Sosyobilimsel konulara dayalı fen öğ retiminin 7. Sınf öğrencilerinin öğrenme ürünleri üzerine etkisi. [Yayımlanmamış Yüksek Lisans Tezi]. Trakya Üniversitesi.

Michelle L. Klosterman, \& Troy D. Sadler (2010) Multi-level assessment of scientific content knowledge gains associated with socioscientific issues-based instruction, International Journal of Science Education, 32(8), 1017-1043. https://doi.org/10.1080/09500690902894512

Moher, D., Liberati, A., Tetzlaff, J., Altman, D.G., The Prisma Group, (2009). Preferred reporting items for systematic reviews and meta-analyses the PRISMA statement. PLoS Med. 6(7), e 1000097 https://doi.org/10.1371/journal.pmed.1000097

*Özcan, C., \& Kaptan, F. (2020). 2008-2017 Yılları arasında sosyobilimsel konulara ilişkin yapılan çalışmaların incelenmesi. Muallim Rıfat Eğitim Fakültesi Dergisi, 2(1), 16-36. https://dergipark.org.tr/en/pub/mrefdergi/issue/52166/634986

*Pehlivan, T. (2020). Sosyobilimsel konulara dayalı fen ĕg itiminin öğ rencilerin akademik başarılarına bilimin doğası anlayışlarına ve argümantasyon becerilerine etkisinin incelenmesi. [Yayımlanmamış Yüksek Lisans Tezi]. Marmara Üniversitesi.

Polat, Ş, Ay, O. (2016). Meta-sentez: Kavramsal bir çözümleme. Eğitimde Nitel Araştırmalar Dergisi, 4(2), 52-64. https://dergipark.org.tr/en/pub/enad/issue/32040/354541

Pluye, P., Gagnon, M.P., Griffiths, F., \& Johnson-Lafleur, J. (2009). A scoring system for appraising mixed-method research, and concomitantly appraising qualitative, quantitative, and mixed-methods primary-level studies in mixed studies reviews. International Journal of Nursing Studies, 46(4), 529-46. http://doi.org/10.1016/j.ijnurstu.2009.01.009

Sadler, T. D. (2004). Informal reasoning regarding socioscientific issues: A critical review of research. Journal of Research in Science Teaching: The Official Journal of the National Association for Research in Science Teaching, 41(5), 513-536. https://doi.org/10.1002/tea.20009

Sadler, T. D., \& Zeidler, D. L. (2005a). The significance of content knowledge for informal reasoning regarding socioscientific issues: Applying genetics knowledge to genetic engineering issues. Science education, 89(1), 71-93. https://doi.org/10.1002/sce.20023

Sadler, T. D., \& Zeidler, D. L. (2005b). Patterns of informal reasoning in the context of socioscientific decision making. Journal of Research in Science Teaching: The Official Journal of the National Association for Research in Science Teaching, 42(1), 112-138. https://doi.org/10.1002/tea.20042

Sadler, T. D. (2009). Situated learning in science education; Socioscientific issues as context for practice. Studies in Science Education, 45, 1-42. https://doi.org/10.1080/03057260802681839

Sadler, T. D. (2011). Situating socio-scientific issues in classrooms as a means of achieving goals of science education. In Sadler, T.D. (Ed.), Socio-scientific issues in the classroom: Teaching, learning, and research. Contemporary Trends and Issues in Science Education 39, (pp. 1-9). 
Sadler, T.D., Romine, W.L., \& Topçu, M.S. (2016). Learning science content through socio-scientific issues-based instruction: a multi-level assessment study, International Journal of Science Education, 38(10), 1622-1635. https://doi.org/10.1080/09500693.2016.1204481

Sadler, T. D. (2011b). Socio-scientific issues based education: What we know about science education in the context of SSI. In Sadler, T.D. (Ed.), Socio-scientific issues in the classroom: Teaching, learning and research. Contemporary Trends and Issues in Science Education 39, (pp. 355-369).

Sandelowski, M., Voils, C.I., \& Barroso, J. (2006). Defining and designing mixed research synshesis studies. Res. Sch., 13, 29-40.

*Şahintürk, G. Y. (2014). Sosyo-bilimsel tartışma destekli fen etkinliklerinin 8. sinıf öğ rencilerinin yenilenebilir enerji kaynakları ile ilgili farkındalıkları ve içerik bilgisi gelişimine etkisinin incelenmesi. [Yayımlanmamış Yüksek Lisans Tezi]. Marmara Üniversitesi.

*Şeçkin Karaca, H (2018). Yapılandırmacı yaklaşım yoluyla sosyobilimsel konulara dayalı fen eğitiminin 7. sını f̈̈̆rencileri üzerine etkileri. ¿Yayımlanmamış Yüksek Lisans Tezi]. Trakya Üniversitesi.

*Şengül, A. A. (2017). Sosyo-bilimsel konularda argümantasyonun ortaokul öğ rencilerinin karar verme becerileri ve akademik başarıları üzerine etkisi. [Yayımlanmamış Yüksek Lisans Tezi]. Mehmet Akif Ersoy Üniversitesi.

Sickel, A. J., Witzig, S. B., Vanmali, B. H., \& Abell, S. K. (2013). The nature of discourse throughout $5 \mathrm{E}$ lessons in a large enrolment college biology course. Research in Science Education, 43(2), 637-665.

https://link.springer.com/article/10.1007/s11165-012-9281-6

*Taşpınar, P. (2011). Sosyobilimsel tartışma destekli sağlık eğitimi etkinliklerinin ilköğ retim 5. sını öğrencilerinde sağlık bilincinin ve içerik bilgisinin gelişimine etkisi. [Yayımlanmamış Yüksek Lisans Tezi]. Marmara Üniversitesi.

Tatar, Ş., \& Adigüzel, O. C. (2019). Türkiye’de tartışmalı ve sosyobilimsel konular üzerine yazılan lisansüstü tezlerin eğitim bilimleri perspektifinden incelenmesi. Eskişehir Osmangazi Üniversitesi Sosyal Bilimler Dergisi, 20, 305-325. https://doi.org/10.17494/ogusbd.548368

Tezel, Ö., \& Günister, B. (2018). Sosyobilimsel konu temelli fen öğretimi üzerine Türkiye'de yapılan çalışmalardan bir derleme. Eskişehir Osmangazi Üniversitesi Türk Dünyası Uygulama ve Araştırma Merkezi Eğitim Dergisi, 3(1), 42-60. https://dergipark.org.tr/en/pub/estudamegitim/issue/40296/481248

*Topaloğlu, M. Y. (2016). Sosyobilimsel konulara dayalı okul dışı öğ renme ortamlarının öğrencilerin kavramsal anlamalarna ve karar verme becerilerine etkisi. [Yayımlanmamış Yüksek Lisans Tezi]. Sakarya Üniversitesi.

Tорсu, M. S. (2010). Development of attitudes towards socioscientific issues scale for undergraduate students. Evaluation Research in Education, 23(1), 51-67. https://doi.org/10.1080/09500791003628187

Topcu, M. S., Muğaloğlu, Z. E, \& Güven, D. (2014). Fen eğitiminde sosyobilimsel konular: Türkiye örneği. Kuram ve Uygulamada Eğitim Bilimleri. 14.(6) 1-22 https://doi.org/10.12738/estp.2014.6.2226

Topçu, M. S. (2019). Sosyobilimsel Konular ve Öğretimi (3. b). Pegem Akademi Türkmen, H., Pekmez, E., \& Saglam, M. (2017). Fen öğretmen adaylarının sosyobilimsel konular hakkındaki düşünceleri. Ege Eğitim Dergisi, 18(2), 448-475. https://doi.org/10.12984/egeefd.295597 
Yapıcıoğlu, A. E., \& Kaptan, F. (2018). Sosyobilimsel durum temelli öğretim yaklaşımının argümantasyon becerilerinin gelişimine katkısı: Bir karma yöntem araştırması. Ondokuz Mayıs Üniversitesi Eğitim Fakiultesi Dergisi, 37(1), 39-61.

Yapıcıoğlu, A. E., \& Atabey, N. (2020). Evaluation of trends in theses on socio-scientific issues: The case of Turkey. International Journal of Progressive Education, 16(4). https://doi.org/10.29329/ijpe.2020.268.8

Yllmaz-Özcan, N., \& Tabak, S. (2019). The effect of argumentation-based social studies teaching on academic achievement, attitude and critical thinking tendencies of students. International Electronic Journal of Elementary Education, 12(2), 213-222. https://doi.org/10.26822/iejee.2019257669

Zeidler, D. L., \& Keefer, M. (2003). The role of moral reasoning and the status of socioscientific issues in science education: Philosophical, psychological and pedagogical considerations. In D. L. Zeidler (Ed.), The role of moral reasoning and discourse on socioscientific issues in science education (pp. 7-38). Kluwer Academic Press.

https://doi.org/10.1007/1-4020-4996-X_2

Zeidler, D. L., \& Nichols, B. H. (2009). Socio-scientific issues: Theory and practice. Journal of Elementary Science Education, 21(2), 49.

*Zengin, F. K., Keçeci, G., \& Kırılmazkaya, G. (2012). İlköğretim öğrencilerinin nükleer enerji sosyo-bilimsel konusunu online argümantasyon yöntemi ile öğrenmesi. Education Sciences, 7(2), 647-654.

https://dergipark.org.tr/en/pub/nwsaedu/issue/19816/211957 


\section{Appendix 1}

A conceptual map of themes that emerged as a result of the thematic synthesis of studies on SSI and their related codes.

\section{Characteristics that educators should have}

- Should be solution-oriented

- Should address current issues

- Should conduct practical activities

- Should be curious

- Should be a researcher

- Should be open-minded

\section{Limitations in SSI Instruction}

- Student age and readiness levels

- Insufficient number of lessons

- Lack of teacher knowledge

- Student prejudices

\section{SSI learning outcomes}

- Affective skills increase

- Concrete learning takes place

- Motivation heightens

- Meaningful and complete learning occurs

- Provides an opportunity for practical activities

- Facilitates remembering

- Enables acquisition of life skills

- Improves higher-order skills

- Encourages teamwork

- Improves decision-making skills

\section{Recommendations for SSI instruction}

- Should be included more in books

- Trainings should be given to the teachers

- Practical activities should be conducted

- Should include out-of-class activities

- Should increase the number of SSI learning outcomes

- Should ensure that students have discussions

- Should increase the number of topics 